\title{
Article \\ Effect of $\gamma$-Heptalactone on the Morphology and Production of Monascus Pigments and Monacolin K in Monascus purpureus
}

\author{
Ruoyu Shi ${ }^{1,2}$, Qiaoqiao Luo ${ }^{1}$, Yutong Liu ${ }^{1}$, Wei Chen ${ }^{1, *}$ and Chengtao Wang ${ }^{1, *}$ \\ 1 Beijing Advanced Innovation Center for Food Nutrition and Human Health, Beijing Engineering and \\ Technology Research Center of Food Additives, Beijing Technology \& Business University (BTBU), \\ Beijing 100048, China; shiruoy@126.com (R.S.); luoqiaoqiao7469@163.com (Q.L.); 18742058299@163.com (Y.L.) \\ 2 Yunnan Plateau Characteristic Agricultural Industry Research Institute, Yunnan Agricultural University, \\ Kunming 650201, China \\ * Correspondence: 20210501@btbu.edu.cn (W.C.); wangchengtao@th.btbu.edu.cn (C.W.)
}

Citation: Shi, R.; Luo, Q.; Liu, Y.; Chen, W.; Wang, C. Effect of $\gamma$-Heptalactone on the Morphology and Production of Monascus Pigments and Monacolin K in Monascus purpureus. J. Fungi 2022, 8, 179. https://doi.org/10.3390/ jof8020179

Academic Editor: Laurent Dufossé

Received: 10 January 2022

Accepted: 7 February 2022

Published: 11 February 2022

Publisher's Note: MDPI stays neutral with regard to jurisdictional claims in published maps and institutional affiliations.

Copyright: (C) 2022 by the authors. Licensee MDPI, Basel, Switzerland. This article is an open access article distributed under the terms and conditions of the Creative Commons Attribution (CC BY) license (https:// creativecommons.org/licenses/by/ $4.0 /)$.

\begin{abstract}
Monascus is used widely in Asian countries and produces various biologically active metabolites, such as Monascus pigments (MPs) and monacolin K (MK). In this study, the effect of $\gamma$-heptalactone on secondary metabolites and mycelial growth during Monascus purpureus M1 fermentation was investigated. After the addition of $50 \mu \mathrm{M} \gamma$-heptalactone, the yields of MPs (yellow, orange, and red) reached maxima, increased by $115.70,141.52$, and $100.88 \%$, respectively. The $25 \mu \mathrm{M}$ $\gamma$-heptalactone groups showed the highest yield of MK was increased by $62.38 \%$ compared with that of the control. Gene expression analysis showed that the relative expression levels of MPs synthesis genes (MpPKS5, MpFasA2, $m p p B, m p p C, m p p D, m p p G, m p p 7$, and $m p p R 1 / R 2)$ were significantly upregulated after $\gamma$-heptalactone treatment. The relative expression levels of MK synthesis genes (mokA, mokC, mokE, mokH, and mokI) were significantly affected. The mycelium samples treated with $\gamma$-heptalactone exhibited more folds and swelling than that in the samples of the control group. This study confirmed that the addition of $\gamma$-heptalactone has the potential to induce yields of MPs and MK, and promote the expression of biosynthesis genes, which may be related to the transformation of mycelial morphology in M. purpureus.
\end{abstract}

Keywords: Monascus purpureus; $\gamma$-heptalactone; Monascus pigments; monacolin K; mycelial morphology

\section{Introduction}

Monascus is a filamentous fungus that has been extensively utilized to color or preserve food and medicine for thousands of years in Southeast Asian countries [1,2]. Monascus can be fermented to produce various functional metabolites, such as Monascus pigments (MPs), monacolin $\mathrm{K}(\mathrm{MK}), \gamma$-aminobutyric acid, ergosterol, enzymes, and organic acids, which are widely used in the food, nutrition, health care, brewing, and medicine industries [3-6].

MPs can be divided into three broad categories, namely yellow, orange, and red [7]. As natural and safe colorants, MPs can be used as functional food ingredients. They provide good coloring effects; can be easily biosynthesized [8,9]; and possess biological activities such as antioxidant, antibacterial, anti-inflammatory, and antitumor properties [10-15]. Therefore, MPs are widely used in the food, medicine, and cosmetics industries, and have good application prospects in the textile, printing, and dyeing industries [16-19]. Monascus purpureus and Monascus rubbers are the two main pigment-producing strains [20-22]. MPs are derived from the fermentation product of Monascus, composed of a polyketone chromophore and medium long-chain fatty acids. At present, six alcohol-soluble pigments (ankaflavin, monascin, monascorubin, rubropunctatin, monascorubramine, and rubropunctamine), which have similar structures, have been identified as the principal pigments of Monascus metabolism and have similar structures [23,24].

MK is a physiologically active polyketone that was first isolated from a culture of M. ruber by Endo in 1979 [25], and is also known as lovastatin in Aspergillus terreus [26]. 
MK is employed as an inhibitor of cholesterol biosynthesis, as it has a similar structure to 3hydroxy-3-methyl glutaryl coenzyme A (HMG-CoA), and can inhibit HMG-CoA reductase activity [27]. MK has been used to regulate blood pressure and blood lipids, and can be developed as a lipid-lowering drug [28-30]. In 2002, Manzoni et al. determined the biosynthetic pathway of lovastatin in A. terreus [31]. Lovastatin biosynthesis is initialized by the catalyzation of lovastatin nine peptide synthase (LNKS) with acetyl CoA and malonyl CoA as the substrates [32]. In 2008, nine genes, termed mokA-mokI, were found in Monascus pilosus, which were highly analogous to the genes (lovB-lovI) of the lovastatin biosynthetic pathway found in A. terreus [33].

Current studies on MPs and MK have mainly focused on improving the yield. Research on MPs and MK production by Monascus submerged fermentation has mainly focused on improving metabolism by optimizing culture conditions and medium components, such as the inoculation amount, temperature, initial $\mathrm{pH}$ value, culture time, oxygen concentration, and nutrients [16,34-37]. Studies have also been performed under conditions such as high salt or sugar stress, and in a low-frequency magnetic field [38-40]. In addition to optimizing the culture medium and fermentation conditions, the biosynthesis of secondary metabolites of Monascus was also promoted by adding exogenous substances, such as glutamate, surfactants, ethanol, rutin, troxerutin, $\alpha$-glucose rutin, ammonium nitrate, linoleic acid, and cAMP [41-47].

Lactones are a group of organic compounds characterized by lactone rings. Lactonecontaining compounds are widely used as the main components of industrial fragrances [48]. Lactones also participate in various metabolic pathways owing to their antioxidant, antibacterial, and anticancer activities [49]. Moreover, $\gamma$-heptalactone induces and enhances penicillin production by shortening the lag period of Aspergillus nidulans, and increasing mycelial branching and spore formation [50]. Previous studies have illustrated that butyrolactone I was found to increase mycelial branching and spore formation, and promote the production of the secondary metabolite lovastatin in A. terreus [51]. In addition, butyrolactone I has been reported to induce a role in lovastatin biosynthesis [52]. Raina [52] and Palonen EK [53] believed that butyrolactone I positively regulated the expression of the global regulator gene laeA in A. terreus, and promoted conidiogenesis and lovastatin biosynthesis.

$\gamma$-Heptalactone and butyrolactones are signaling molecules that affect the secondary metabolism and mycelial growth in the filamentous fungi $A$. nidulans and A. terreus. Previous studies have shown that lactones affect the production of lovastatin in A. nidulans, but the effect of lactones on Monascus has not been reported. This study aimed to determine whether lactones act as signaling molecules in the secondary metabolites of Monascus.

In the present study, the effect of $\gamma$-heptalactone on the biosynthesis of secondary metabolites in $M$. purpureus was investigated. The effect of different $\gamma$-heptalactone concentrations $(0,25,50$, and $100 \mu \mathrm{M})$ on the yield of MPs and MK was studied during $M$. purpureus fermentation. Moreover, the expression levels of MPs and MK biosynthesis genes and asexual development genes $(\operatorname{brl} A, \operatorname{wet} A$, and $l a e A)$ were analyzed to reveal the potential mechanism using real-time quantitative polymerase chain reaction (RT-qPCR). The morphology of mycelia and spores was observed by using a light microscope and scanning electron microscope (SEM), respectively. This study was mainly aimed at investigating the regulatory effect of $\gamma$-heptalactone on MPs and MK biosynthesis, the change in morphology and sporulation, and the improvement of the final yield of desired metabolites in M. purpureus.

\section{Materials and Methods}

\subsection{Microorganism and Media}

The M. purpureus M1 strain (CGMCC 3.0568) preserved in the laboratory was selected for this study. The strain was activated on the potato dextrose agar (PDA) medium (20 g/L glucose, $3 \mathrm{~g} / \mathrm{L}$ peptone, $4 \mathrm{~g} / \mathrm{L}$ yeast, $20 \mathrm{~g} / \mathrm{L}$ malt, $20 \mathrm{~g} / \mathrm{L}$ agar, $2 \mathrm{~g} / \mathrm{L} \mathrm{KH}_{2} \mathrm{PO}_{4}, 2 \mathrm{~g} / \mathrm{L}$ $\mathrm{NaNO}_{3}$, and $\left.1 \mathrm{~g} / \mathrm{L} \mathrm{MgSO}_{4} \cdot 7 \mathrm{H}_{2} \mathrm{O}\right)$ at $30{ }^{\circ} \mathrm{C}$ for 5 days [54]. The spore suspension $\left(10^{6} / \mathrm{mL}\right)$ was prepared and inoculated into $50 \mathrm{~mL}$ of seed liquid medium $(30 \mathrm{~g} / \mathrm{L}$ glucose, $15 \mathrm{~g} / \mathrm{L}$ 
soybean meal, $10 \mathrm{~g} / \mathrm{L}$ peptone, $70 \mathrm{~mL} / \mathrm{L}$ glycerol, $2 \mathrm{~g} / \mathrm{L} \mathrm{KH}_{2} \mathrm{PO}_{4}, 2 \mathrm{~g} / \mathrm{L} \mathrm{NaNO}$, and $1 \mathrm{~g} / \mathrm{L} \mathrm{MgSO}_{4} \cdot 7 \mathrm{H}_{2} \mathrm{O}$ ) with $10 \%$ volume of inoculum. The seed culture was kept at $30{ }^{\circ} \mathrm{C}$ and $200 \mathrm{rpm}$ (HZQ-F160, China) for $48 \mathrm{~h}$ in a 250-mL Erlenmeyer flask (This culture was nominated as the seed culture) $[54,55]$.

\subsection{Production of $M P s$ and $M K$}

The seed culture $(10 \% v / v)$ was used to inoculate the MPs and MK production medium $\left(20 \mathrm{~g} / \mathrm{L}\right.$ rice powder, $1 \mathrm{~g} / \mathrm{L} \mathrm{MgSO} 4 \cdot 7 \mathrm{H}_{2} \mathrm{O}, 2 \mathrm{~g} / \mathrm{L} \mathrm{ZnSO}_{4} \cdot 7 \mathrm{H}_{2} \mathrm{O}, 2.5 \mathrm{~g} / \mathrm{L} \mathrm{KH}_{2} \mathrm{PO}_{4}, 90 \mathrm{~g} / \mathrm{L}$ glycerol, $5 \mathrm{~g} / \mathrm{L} \mathrm{NaNO}_{3}$, and $10 \mathrm{~g} / \mathrm{L}$ peptones). Then, the inoculated production medium was cultured at $30{ }^{\circ} \mathrm{C}$, at $200 \mathrm{rpm}$ for 2 days. After that, the culture was incubated at $25^{\circ} \mathrm{C}$, at $150 \mathrm{rpm}$ for 13 days [54,55]. Experimental lactone groups of $\gamma$-heptalactone, $\gamma$-butyrolactone, $\gamma$-caprolactone, $\gamma$-valerolactone, and $\gamma$-octalactone were added to the fermentation medium with $100 \mu \mathrm{M}$ concentration. $\gamma$-heptalactone was added to the fermentation medium at different concentrations $(0,25,50$, and $100 \mu \mathrm{M})$ on the second day to identify the optimal concentration.

\subsection{Determination of $M P S$}

The analysis method of M. purpureus pigments was modified according to Chen et al. $[56,57]$. The fermentation broths were extracted with $70 \%$ ethanol, soaked in a water bath at $60{ }^{\circ} \mathrm{C}$ for $1 \mathrm{~h}$ in dark, and then filtered. Then, the absorbance at 505, 448, and $410 \mathrm{~nm}$ were determined. The color values of the pigments were obtained by multiplying the absorbance value with the dilution factor [58].

$$
\begin{aligned}
& \text { Yellow pigment color value }(\mathrm{U} / \mathrm{mL})=\mathrm{OD} \text { at } 410 \times \text { dilution factor } \\
& \text { Orange pigment color value }(\mathrm{U} / \mathrm{mL})=\mathrm{OD} \text { at } 448 \times \text { dilution factor } \\
& \text { Red pigment color value }(\mathrm{U} / \mathrm{mL})=\mathrm{OD} \text { at } 505 \times \text { dilution factor }
\end{aligned}
$$

\subsection{HPLC Analysis of MK Production}

To determine the yield of MK, the fermentation broth was mixed with $70 \%$ methanol, and $30 \mathrm{~min}$ sonication treatment $(250 \mathrm{~W}, 40 \mathrm{kHz})$ was conducted to extract MK. After centrifugation at $8000 \mathrm{~g}$ for $5 \mathrm{~min}$, the supernatant was filtered through a $0.22 \mu \mathrm{m}$ membrane for detection by HPLC (LC-20AT, Shimadzu, Kyoto, Japan) [59].

HPLC analysis was performed under the following conditions: Inertsil ODS-3 C18 column $(150 \mathrm{~mm} \times 4.6 \mathrm{~mm} \times 5 \mu \mathrm{m})$, mobile phase $\left(0.1 \% \mathrm{H}_{3} \mathrm{PO}_{4}\right.$ : methanol $\left.=35: 65, v / v\right)$, flow rate of $1 \mathrm{~mL} / \mathrm{min}$, column temperature of $30^{\circ} \mathrm{C}$, an ultraviolet detector detected the wavelength at $237 \mathrm{~nm}$, and an injection volume of $10 \mu \mathrm{L}$ [60].

\subsection{Microscopy Analysis of Monascus Mycelia and Spore}

The growth and development of the mycelium and spore morphology were observed by using a light microscope (CX43, Olympus, Japan) and scanning electron microscope (SEM; Su8020, Hitachi Ltd., Tokyo, Japan). To observe the effect of $\gamma$-heptalactone on mycelial growth, $10 \mu \mathrm{L}$ spore suspension was inoculated on PDA and was cultured at $30{ }^{\circ} \mathrm{C}$, and the morphology was observed with a microscope. For the SEM analysis, the mycelium was fixed in a $2.5 \%$ glutaraldehyde solution for $12 \mathrm{~h}$ and washed twice with $0.1 \mathrm{M}$ phosphate buffer ( $\mathrm{pH}$ 7.2). Then, the mycelium was dehydrated with different concentrations of ethanol solution $(30,50,70,80,90$, and 100\%) and each was repeated twice. The mycelium was collected after centrifugation at 12,000 rpm for $5 \mathrm{~min}$ and the supernatant was discarded. Then, the solvent hexamethyldisilazane (HMDS) was added and the sample was dried in the oven at $60^{\circ} \mathrm{C}$ until it became powder [55]. The mycelial sample was observed using a Su8020 SEM (Hitachi Ltd., Tokyo, Japan). 


\subsection{Real-Time Quantitative PCR Analysis of MPs and MK Biosynthesis-Related Genes}

Gene expression analysis was performed by RT-qPCR according to the methods of Zhang and Yang [54,55]. The total RNA from the mycelium was extracted by the polysaccharide polyphenol plant total RNA extraction Kit (Tiangen, Beijing, China). The first-strand cDNA was synthesized with a FastQuant RT Kit (with gDNase) (Tiangen, Beijing, China) and the SuperReal PreMix Plus (SYBR Green) kit (Tiangen, Beijing, China). RT-qPCR was accomplished using a CFX96 Real-Time PCR detection system (Bio-Rad, Hercules, CA, USA). The amplification cycle was as follows: $95^{\circ} \mathrm{C}$ for $15 \mathrm{~min}$, followed by a three-step PCR $\left(40\right.$ cycles of denaturation at $95{ }^{\circ} \mathrm{C}$ for $10 \mathrm{~s}$, annealing at $52{ }^{\circ} \mathrm{C}$ for $20 \mathrm{~s}$, and extension at $72{ }^{\circ} \mathrm{C}$ for $30 \mathrm{~s}$ ) [60,61]. The levels of relative expression were calculated by the $2^{-\triangle \triangle \mathrm{Ct}}$ method. All values were normalized using the transcription level of the GAPDH gene. RT-qPCR was conducted in triplicate for each sample. Primers for MPs biosynthesis genes (GenBank accession no. MK764693.1), mokA-mokI (GenBank accession no. DQ176595.1), and GAPDH (GenBank accession no. HQ123044.1) were designed by Beacon Primer Premier 5 software, as shown in Table 1.

\subsection{Statistical Analysis}

Each experiment was repeated at least thrice. All statistical analyses were performed by one-way analysis of variance (ANOVA) using GraphPad prime 9.0. Numerical data were expressed as mean $\pm \mathrm{SD}$, and $p$-values $<0.05$ and $<0.01$ were considered statistically significant.

Table 1. Primer sequences for the key genes in M. purpureus M1.

\begin{tabular}{|c|c|c|c|c|c|}
\hline Genes & Primer sequences $\left(5^{\prime}\right.$ to $\left.3^{\prime}\right)$ & Length (bp) & Tm Value & $\begin{array}{l}\text { PCR Product } \\
\text { Length (bp) }\end{array}$ & Description \\
\hline$M p P K S 5 \mathrm{~F}$ & TGTCCGACGAGTTTCTGCAA & 20 & 58 & 134 & \multirow{2}{*}{ NR-PKS } \\
\hline MpPKS5 R & TATCAACGCTGCTTGGGCAT & 20 & 60 & 134 & \\
\hline$M p F a s A 2 \mathrm{~F}$ & ATGGATCGCCCGATCTTGTC & 20 & 59 & 129 & \multirow{2}{*}{ FAS subunit alpha } \\
\hline$M p F a s A 2 \mathrm{R}$ & CTTTGTCGAGTCCGCTGGAT & 20 & 59 & 129 & \\
\hline$M p F a s B 2 \mathrm{~F}$ & CCTCCAGGGATTACAACCCG & 20 & 58 & 131 & \multirow[b]{2}{*}{ FAS subunit beta } \\
\hline MpFasB2 R & ATTCAATGCCAGGTGCTCCA & 20 & 58 & 131 & \\
\hline$m p p A \mathrm{~F}$ & TCCCGTTTCTTGGACGTGAG & 20 & 59 & 132 & \multirow{2}{*}{ C-11-ketoreductase } \\
\hline$m p p A R$ & ACGTGCCATGGTTCTGTCTT & 20 & 59 & 132 & \\
\hline$m p p B \mathrm{~F}$ & CGTCTCGCCCGATAACTTCA & 20 & 60 & 108 & \multirow{2}{*}{ acyltransferase } \\
\hline$m p p B R$ & TTGACAGACGGGTCGAAGTC & 20 & 58 & 108 & \\
\hline$m p p C \mathrm{~F}$ & CAGTCCTCGTCCCTTCCAGT & 20 & 60 & 137 & \multirow{2}{*}{$\begin{array}{l}\text { NADPH-dependent } \\
\text { oxidoreductase }\end{array}$} \\
\hline$m p p C \mathrm{R}$ & CCACGGTGAAGGATGTCGAG & 20 & 58 & 137 & \\
\hline$m p p D \mathrm{~F}$ & TCAACACGGGAGATGCTGTC & 20 & 62 & 140 & \multirow{2}{*}{ serine hydrolase } \\
\hline$m p p D \mathrm{R}$ & GCCAAAGGACAGGAGCAGAT & 20 & 63 & 140 & \\
\hline mppE F & CTTCCCGATGCCGTTGTGAT & 20 & 60 & 99 & \multirow{2}{*}{ enoyl reductase } \\
\hline mppE R & GTCTCGTGGATCATCTCGT & 19 & 60 & 99 & \\
\hline$m p p G \mathrm{~F}$ & TCAACACGGGAGATGCTGTC & 20 & 56 & 140 & \multirow{2}{*}{$\begin{array}{l}\text { FAD-dependent } \\
\text { oxidoreductase }\end{array}$} \\
\hline$m p p G R$ & GCCAAAGGACAGGAGCAGAT & 20 & 59 & 140 & \\
\hline$m p p 7 \mathrm{~F}$ & ATCGTCGGATCAGCGTCAC & 19 & 59 & 148 & \multirow{2}{*}{ acetylatransferase } \\
\hline$m p p 7 \mathrm{R}$ & CGGCTGTTATAGGGTGGC & 18 & 57 & 148 & \\
\hline $\operatorname{mppR1\mathrm {F}}$ & TCTGCAGTATGCCATGTGGG & 20 & 59 & 123 & \multirow{2}{*}{ transcription factor } \\
\hline mppR1 R & ATGGCACCGTCACTTAGCTC & 20 & 55 & 123 & \\
\hline$m p p R 2 \mathrm{~F}$ & ACGAAACCCTCCATGACACC & 20 & 59 & 138 & \multirow{2}{*}{ transcription factor } \\
\hline$m p p R 2 \mathrm{R}$ & TGCAGACAGCCTTGTGGTAG & 20 & 59 & 138 & \\
\hline$m o k A \mathrm{~F}$ & GACCTCGGTCATCTTGGC & 18 & 57 & 78 & \multirow{2}{*}{ polyketide synthase } \\
\hline$m o k A \mathrm{R}$ & TTGTTCCAAGCGGTCTTC & 18 & 54 & 78 & \\
\hline$m o k B \mathrm{~F}$ & AAACATCGTCACCAGTCT & 18 & 53 & 78 & \multirow{2}{*}{ polyketide synthase } \\
\hline$m o k B \mathrm{R}$ & CTAAGTCGGGCATCTACC & 18 & 53 & 78 & \\
\hline
\end{tabular}


Table 1. Cont.

\begin{tabular}{|c|c|c|c|c|c|}
\hline Genes & Primer sequences $\left(5^{\prime}\right.$ to $\left.^{\prime}\right)$ & Length (bp) & Tm Value & $\begin{array}{l}\text { PCR Product } \\
\text { Length }(b p)\end{array}$ & Description \\
\hline mokC F & CAAGCTGCGAAATACACCAAGCCTC & 25 & 62 & 80 & \multirow{2}{*}{ P450 monooxygenase } \\
\hline $\operatorname{mokC} R$ & AGCCGTGTGCCATTCCTTGTTGTCC & 25 & 60 & 80 & \\
\hline$m o k D \mathrm{~F}$ & TTCATCTGCTGCTGGTAT & 18 & 53 & 92 & \multirow[b]{2}{*}{ oxidoreductase } \\
\hline$m o k D \mathrm{R}$ & AACTTCTCACCGTCAATG & 18 & 52 & 92 & \\
\hline mokE F & ATCGCAGGTCACGCACATCCAAGTC & 25 & 65 & 221 & \multirow{2}{*}{ dehydrogenase } \\
\hline mokE R & GTAAAGGCAGCCCGAGCAGCTTCAT & 25 & 65 & 221 & \\
\hline mokF F & GAGATCATAGTGGCCGACTGAA & 22 & 60 & 190 & \multirow[b]{2}{*}{ transesterase } \\
\hline$m o k F \mathrm{R}$ & ACCGTCTCATCCAACCTCACGA & 22 & 61 & 190 & \\
\hline$m o k G \mathrm{~F}$ & CCAGGTAACCAACGGATTA & 19 & 51 & 82 & \multirow{2}{*}{ HMG-CoA reductase } \\
\hline$m o k G \mathrm{R}$ & GATCAGAGCAGTCACCAG & 18 & 54 & 82 & \\
\hline$m o k H \mathrm{~F}$ & CAGGAAATCTGGACTTACCCCATTG & 25 & 58 & 123 & \multirow{2}{*}{ transcription factor } \\
\hline$m o k H \mathrm{R}$ & TGTTGGATTGTTGTTGGAGATATAC & 25 & 55 & 123 & \\
\hline mokI F & CAGGAAATCTGGACTTACCCCATTG & 20 & 60 & 135 & \multirow{2}{*}{ efflux pump } \\
\hline$m o k I \mathrm{R}$ & TGTTGGATTGTTGTTGGAGATATAC & 18 & 57 & 135 & \\
\hline laeA F & ACTCGTAGCGGATGTAAGA & 19 & 55 & 105 & \multirow{2}{*}{ global regulator } \\
\hline laeA $\mathrm{R}$ & CCGTGCTTGGTAGATGTG & 18 & 55 & 105 & \\
\hline brIA F & ATGTCAGGGTGGCGTGAAGT & 20 & 60 & 187 & \multirow{2}{*}{ asexual development } \\
\hline brIA R & CCTGAACTGTACCTGCTTGAT & 21 & 56 & 187 & \\
\hline wet $A \mathrm{~F}$ & ATGTGTTATATTCCCCGGGA & 20 & 60 & 174 & \multirow{2}{*}{ asexual development } \\
\hline wetA R & TTAGCAGAGTGCGGCCTCGAG & 21 & 62 & 174 & \\
\hline GAPDH F & CCGTATTGTCTTCCGTAAC & 19 & 55 & 114 & \multirow{2}{*}{ Reference gene } \\
\hline GAPDH R & GTGGGTGCTGTCATACTTG & 19 & 56 & 114 & \\
\hline
\end{tabular}

\section{Results}

\subsection{Effect of Lactones on Secondary Metabolites in M. purpureus}

The effects of exogenously added lactones ( $\gamma$-heptalactone, $\gamma$-butyrolactone, $\gamma$-caprolactone, $\gamma$-valerolactone, and $\gamma$-octalactone) on the biosynthesis of secondary metabolites are shown in Figure 1. As shown in Figure $1 \mathrm{a}-\mathrm{c}$, the maximum yields of MPs were higher in the $\gamma$-heptalactone and $\gamma$-butyrolactone groups than in the control group. The yield of MK was significantly promoted in the $\gamma$-heptalactone and $\gamma$-butyrolactone groups $(p<0.01)$ compared with the control group, while other substances showed no such effect (Figure 1d).

\subsection{Effect of $\gamma$-Heptalactone on the Yield of MPs and MK in M. purpureus}

After the addition of $\gamma$-heptalactone, the yields of MPs and MK were analyzed throughout the fermentation process (Figure 2). The yields of yellow, orange, and red pigments at different culture periods $(2,5,8,12$, and 15 days) were detected by spectrophotometry (Figure $2 \mathrm{a}-\mathrm{c}$ ). With the increase in $\gamma$-heptalactone concentration, the yield of MPs increased at first, but finally dropped to the same level as that in the control group. Although pigment production during the initial period (0-2 days) did not change, the addition of 25 and $50 \mu \mathrm{M} \gamma$-heptalactone resulted in higher pigment production after 5 days of incubation. The changes in the yields of the three pigments were generally consistent. In particular, the most significant increase was observed for the 25 and $50 \mu \mathrm{M} \gamma$-heptalactone treatment $(p<0.01)$. On the twelfth day, the MPs yield reached maximum level with $\gamma$-heptalactone doses of $50 \mu \mathrm{M}$, and the yield of yellow pigment, orange pigment, and red pigment was $115.70,141.52$, and $100.88 \%$, respectively, higher than that of the control group, reaching 67.05 U/mL, $53.83 \mathrm{U} / \mathrm{mL}$, and 86.25 U/mL, respectively. The MK yield was gradually stimulated with the $\gamma$-heptalactone treatment compared with that in the control from day 8 to day 15 (Figure 2d). The 25 and $50 \mu \mathrm{M} \gamma$-heptalactone groups showed the highest MK production on day 12 , which was increased by 62.38 and $43.82 \%$, respectively, compared with the control group. However, when $100 \mu \mathrm{M} \gamma$-heptalactone was added, the yield of MK reached its peak on day 12 and then dropped on day 15. The maximum yield of MK was achieved after 15 days of culture with $25 \mu \mathrm{M}$ of lactone, which was $62.38 \%$ higher than that in the control group. 


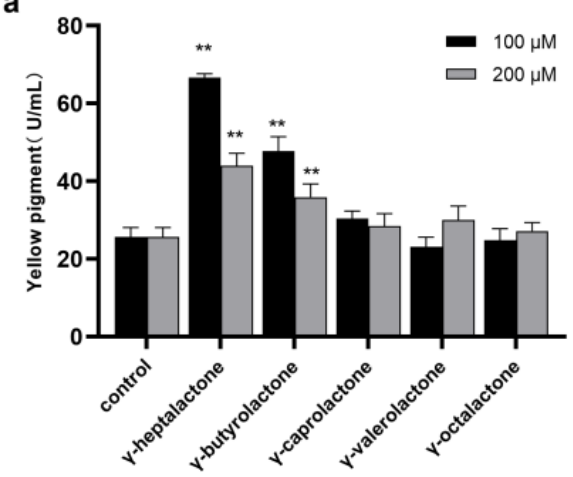

c

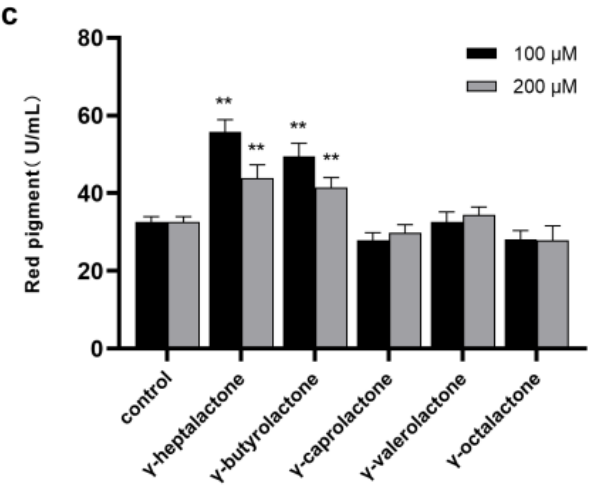

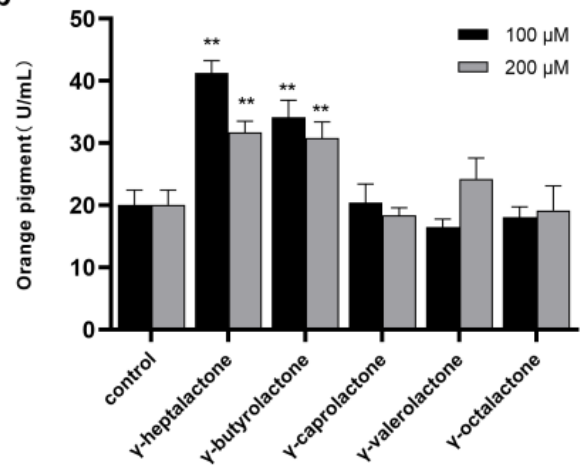

d

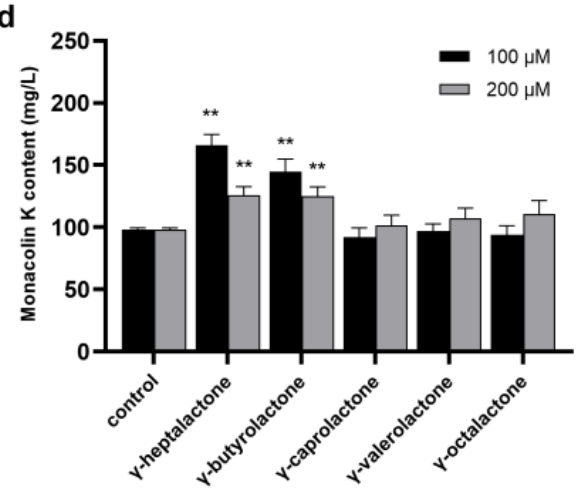

Figure 1. Effect of five lactones ( $\gamma$-heptalactone, $\gamma$-butyrolactone, $\gamma$-caprolactone, $\gamma$-valerolactone, and $\gamma$-octalactone) on the MPs and MK synthesis in M. purpureus M1. (a) Yellow pigment, (b) orange pigment, (c) red pigment, and (d) MK. Data are expressed as the mean $\pm \operatorname{SD}(n=3) .{ }^{* *} p<0.01$, compared to the control.

a
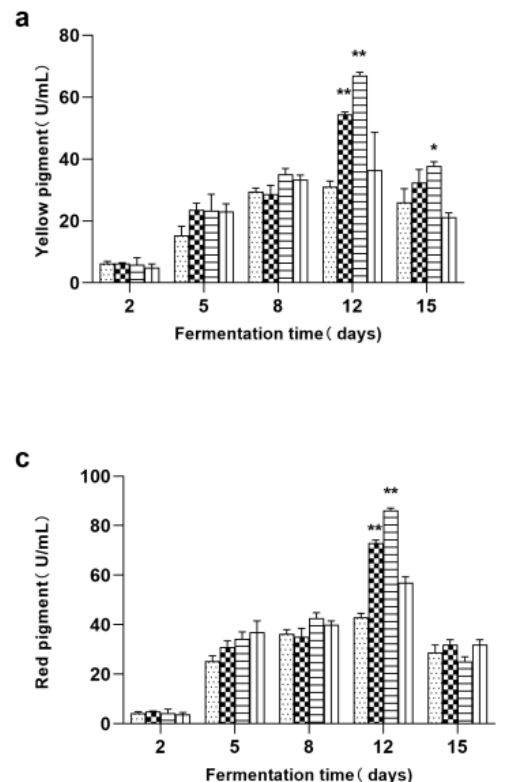

b
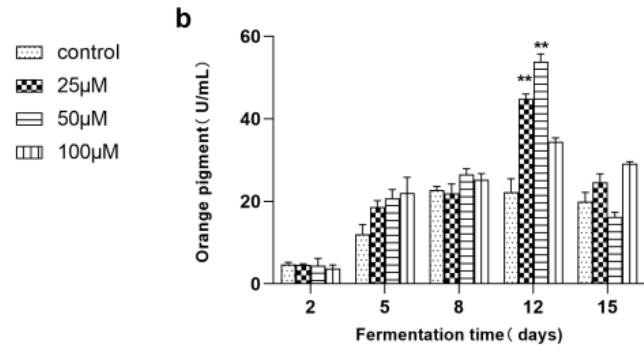

$\square$ control

$\infty 25 \mu \mathrm{M}$

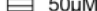

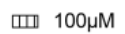

Figure 2. Effect of different $\gamma$-heptalactone concentrations on the yield of MPs and MK in M. purpureus M1. (a) Yellow pigment, (b) orange pigment; (c) red pigment, and (d) MK. Data are expressed as the mean $\pm \mathrm{SD}(n=3) .{ }^{*} p<0.05$ and ${ }^{* *} p<0.01$, compared to the control. 


\subsection{Effect of $\gamma$-Heptalactone on the Expression of MPs Biosynthesis-Related Genes}

To investigate the effects of $\gamma$-heptalactone on MPs biosynthesis, we measured the expression levels of $M p P K S 5, M p F a s A 2, M p F a s B 2, m p p A, m p p B, m p p C, m p p D, m p p E$, $m p p G$, $m p p 7, m p p R 1$, and $m p p R 2$ genes using RT-qPCR. As shown in Figure 3, the relative levels of MpPKS5, MpFasA2, mppC, and mppE genes were upregulated by 3.64-, 3.44-, 1.52-, and 1.36-fold, respectively, compared with the control group on day 8 . On day 12 , the expression levels of the $m p p A, m p p B$, and $m p p D$ genes increased by 1.94-, 7.51-, and 1.96fold, respectively. The expression levels of $m p p 7$ and $m p p G$ were upregulated by 2.79 - and 3.21-fold on day 15, respectively, whereas the expression levels of MpFasB2, mppA, and $m p p E$ did not change. The expression levels of two transcription factors MppR1 and MppR2 were increased by 1.55- and 3.86-fold, respectively, compared to that in the control.
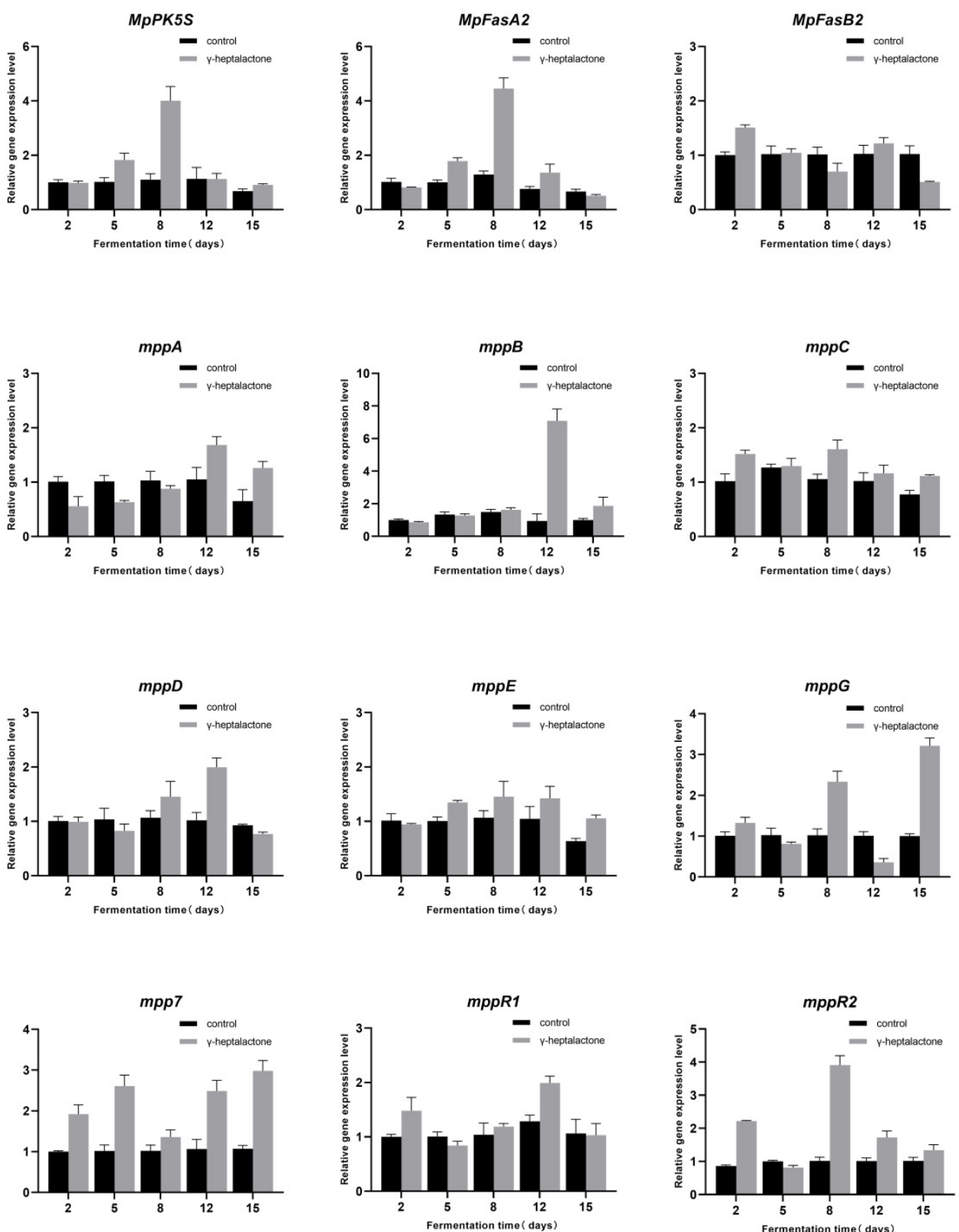

Figure 3. Effect of $\gamma$-heptalactone on the relative gene expression levels of MPs biosynthesis genes.

\subsection{Effect of $\gamma$-Heptalactone on the Expression of MK Biosynthetic Gene Cluster}

To investigate the effect of $\gamma$-heptalactone on MK metabolism, we measured the expression level of the MK biosynthetic gene cluster (mokA-mokI) by RT-qPCR(Figure 4). 
The expression level of mokB on day two was 1.56-fold higher than that in the control group. The expression level of $m o k F$ reached its peak on day 5 , which was 2.55 -fold higher than the control group. On day 8 , the expression levels of mokC, mokD, mokE, and mokG genes were significantly up-regulated in the treatment group, which were increased by 2.78-, 2.23-, 7.53-, and 1.82-fold, respectively. The mok $A$ and mokI genes reached the peak on day 12 and were increased by 2.59- and 2.72-fold, respectively, compared with the control group. The expression of mokH gene reached its highest level on day 15, which was 3.42-fold higher than that in the control group.
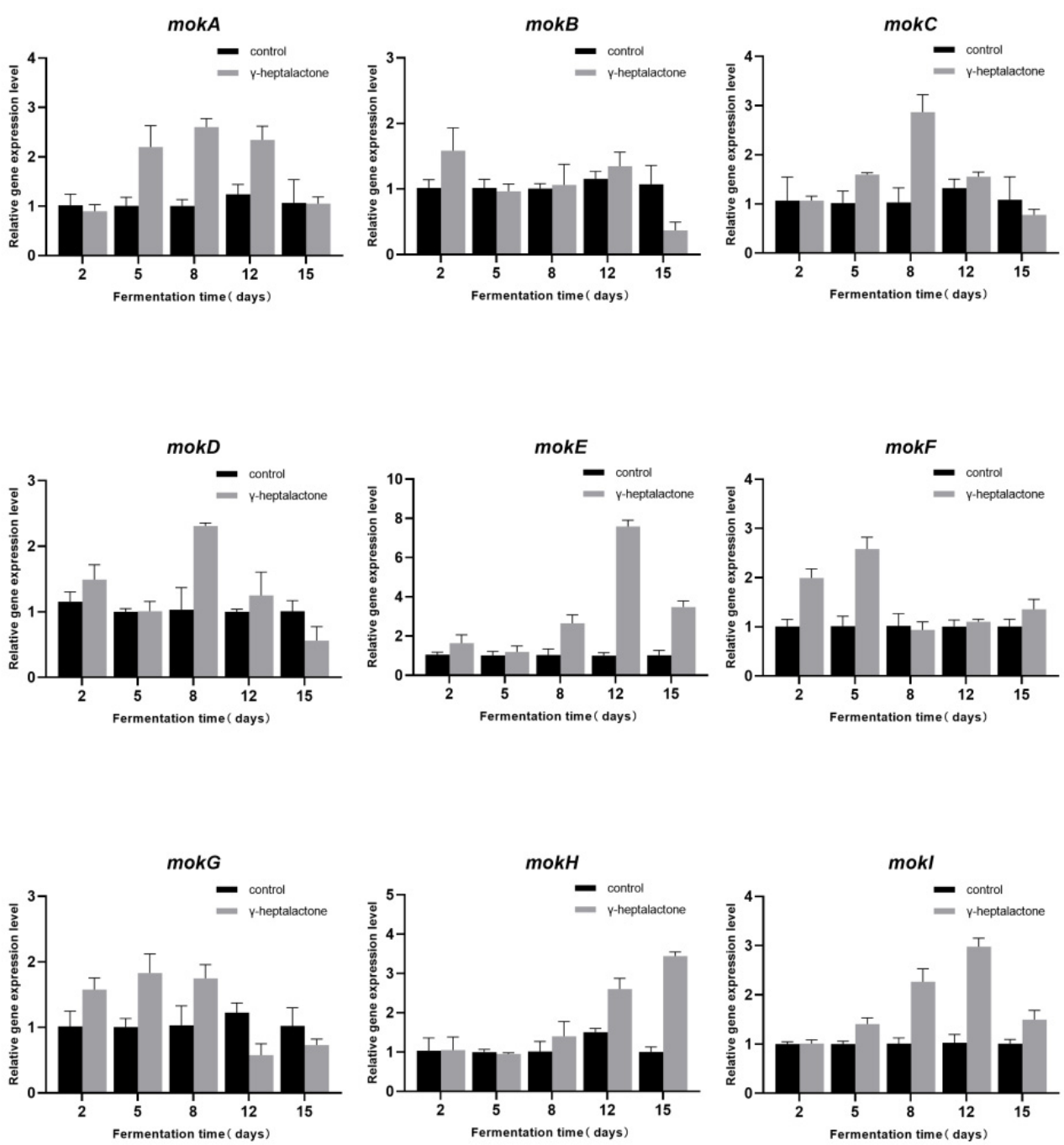

Figure 4. Effect of $\gamma$-heptalactone on the relative expression levels of MK biosynthesis genes (mokA-I).

\subsection{Effect of $\gamma$-Heptalactone on the Mycelial and Spore Morphology of M. purpureus}

Monascus purpureus M1 spore suspension was cultured on PDA (with/without $\gamma$ heptalactone) and was observed using a light microscope (at $400 \times$ magnifications) (Figure 5a). Mycelial growth and development were dramatically increased after $\gamma$-heptalactone treatment, and conidial germination was detected at the end of the mycelium at $24 \mathrm{~h}$. At $72 \mathrm{~h}$, there were many conidia formed, which was much more in the treated group than that in the control group. Ascospore formation was observed at $84 \mathrm{~h}$, and the number of ascospores in the $\gamma$-heptalactone-treated group increased compared to the control group. At $120 \mathrm{~h}$, the number of ascospores in the control group was reduced, but many ascospores could still be observed in the treated group. 
a

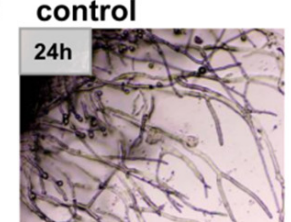

$\mathrm{y}$-heptalactone

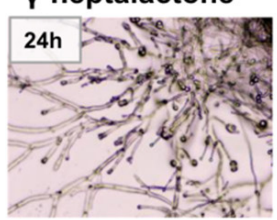

b

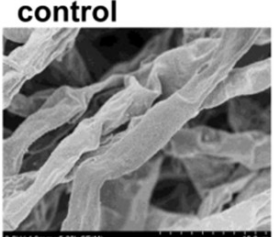

\section{Y-heptalactone}

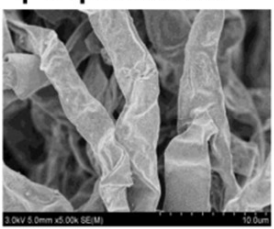

c

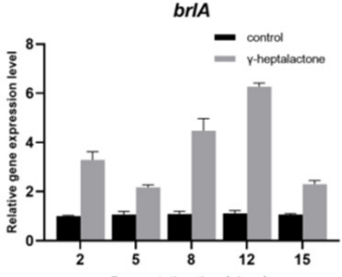

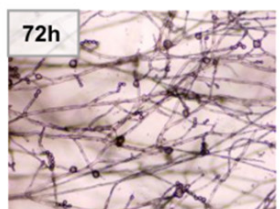
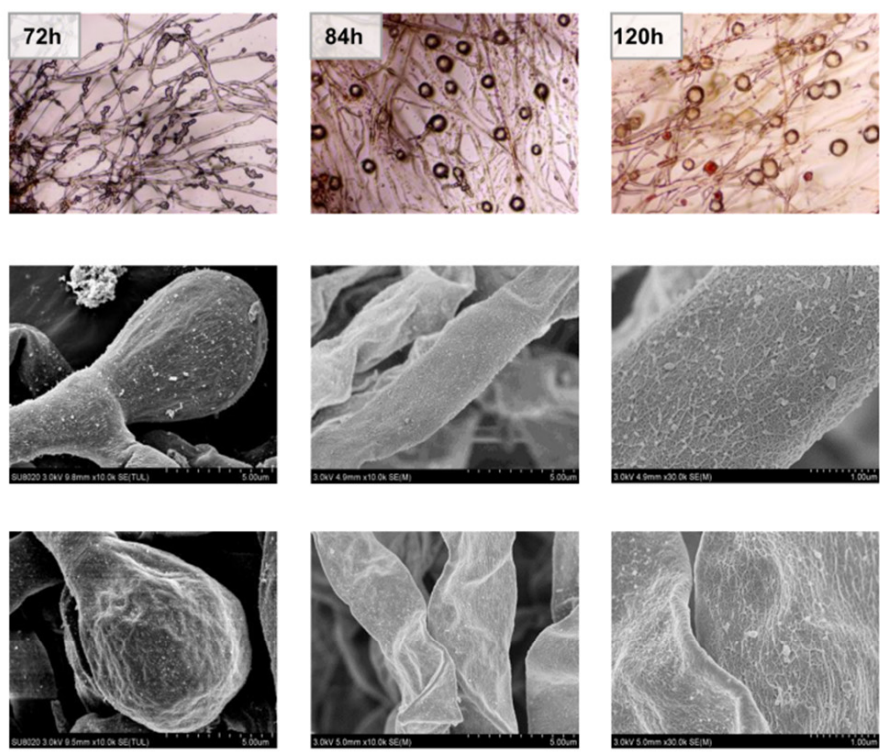

wetA
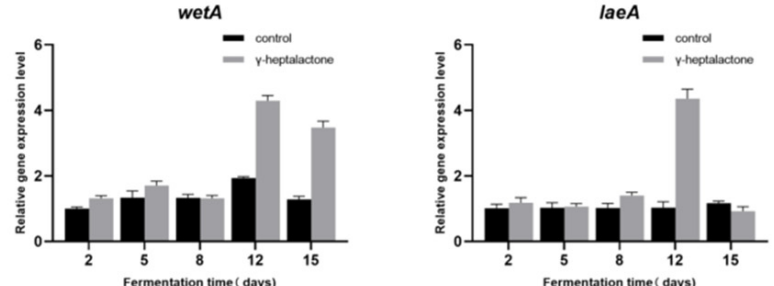

Figure 5. Effect of $\gamma$-heptalactone on micromorphology and the expression of asexual development genes of the M. purpureus M1. (a) Morphology of the M. purpureus after cultivation on PDA at $30^{\circ} \mathrm{C}$ for $120 \mathrm{~h}$ (at $400 \times$ magnifications). (b) Scanning electron microscope images of the mycelium and spores at $5000 \times, 10,000 \times$, and 30,000×. (c) Relative expression levels of laeA, brIA, and wetA based on RT-qPCR.

To observe the structures of $M$. purpureus mycelium and spores, samples were assessed using a scanning electron microscope (SEM; at 5000 $\times, 10,000 \times$, and 30,000 $\times$ magnifications), as shown in Figure $5 \mathrm{~b}$. The mycelial surface with the $\gamma$-heptalactone treatment exhibited folds and expansion, whereas the mycelia in the control group were fuller with a smooth surface. The pitting and folding degree of the spores in the $\gamma$-heptalactone-treated group were markedly higher than those in the control group. More secretions were accumulated in the treated group than that in the control group. Additionally, RT-qPCR was performed on two central regulators (brlA and wet $A$ ) and a global regulator (laeA) in $M$. purpuureus $M 1$ to investigate the impact of $\gamma$-heptalactone on spores at the transcriptional level. As shown in Figure $5 c$, the results indicated that after $\gamma$-heptalactone treatment, the expression levels of laeA, brIA, and wetA genes were increased by 3.68-, 5.70-, and 2.25-fold, respectively, compared to those in the control.

\section{Discussion}

Lactone molecules, as inductive agents, regulate the cell growth and synthesis of secondary metabolites in Aspergillus [51,52]. The addition of butyrolactone I is a potential approach to increase the production of lovastatin in Aspergillus terreus [53]. Because the MK 
biosynthetic pathway in Monascus is very similar to the lovastatin biosynthetic pathway in A. terreus, we speculate that lactone might be able to improve the production of MK in M. purpureus [29]. We selected five lactones for testing and found that both $\gamma$-butyrolactone and $\gamma$-heptalactone could promote MPs and MK production in M. purpureus, with $\gamma$ heptalactone having the most pronounced effect. Additionally, the mycelium and spore morphology were also significantly affected by the treatment with $\gamma$-heptalactone. This result coincided with Erkaya's study, which indicated that inductive molecules such as tyrosol and farnesol could increase MPs production [62].

MPs and MK are the best-known secondary metabolites produced by Monascus strains, and their biosynthetic pathways have been elucidated $[29,56,57]$. Treatment with $\gamma$-heptalactone was assayed to increase the yields of three MPs (yellow, orange, and red pigments) by $115.70,141.52$, and $100.88 \%$, and reached $67.05,53.83$, and $86.25 \mathrm{U} / \mathrm{mL}$, respectively (Figure 2a-c). The biosynthesis of MPs is regulated by genes encoding various polyketide synthases (PKSs), fatty acid synthases (FASs), dehydrogenases, transporters, and regulatory factors. Therefore, analysis of the expression levels of MPs biosynthesis-related with or without $\gamma$-heptalactone treatment was performed [63-65]. The results showed that the expression levels of most of the tested genes were significantly upregulated, such as MpPKS5 (encoding a PKS), MpFas 2 2 (encoding a FAS), mppB (encoding an acetyltransferase), $m p p C / G$ (encoding oxidoreductases), $m p p 7$ (encoding an acyltransferase), and $m p p R 1 / R 2$ (encoding regulatory proteins), which increased the yield of MPs (Figure 3). It can be speculated that by upregulating $M p P K S 5, M p F a s A 2$, and $m p p B$, the relative activities of $\beta$-ketoacid and hexoketochromophore enzymes were increased, thus improving the metabolic pathway of the pigment synthesis. In addition, the $m p p C, m p p 7$, and $m p p G$ genes were also upregulated, promoting the conversion of orange and yellow pigments.

The maximum increase in MK production was observed when cells were treated with $25 \mu \mathrm{M} \gamma$-heptalactone. The yield of MK reached $187.44 \mathrm{mg} / \mathrm{L}$ on day 15 , which was $62.38 \%$ higher than that in the control $(p<0.05)$. At least nine key genes are associated with MK biosynthesis. In the presence of $\gamma$-heptolactone, mokA, mokC, mokE, mokH, and mokI were significantly affected. MK production in the mokA-dissrupted Monascus strain has been reported to be completely blocked, indicating the importance of the mokA gene in MK biosynthesis [29,32,66]. Meanwhile, the overexpression of mokC, mokE, and mokH significantly affects MK anabolism [60,61]. The mokI gene encodes the MokI protein, which functions as an efflux pump [55]. The results pertaining to the mokI gene were consistent with those of previous studies; the expression level of mokI was much higher in the treated group, implying a significant effect of $\gamma$-heptalactone on the anabolism of MK. We predicted that $\gamma$-heptalactone might facilitate MK production partly by improving its secretion and reducing the intracellular content.

Previous studies have illustrated the maximal orange and red pigments as 133.77 and $108.02 \mathrm{U} / \mathrm{mL}$, respectively, after 10 days at $30{ }^{\circ} \mathrm{C}$ with $150 \mathrm{rpm}$ [58]. In our study, $\gamma$-heptalactone was assayed to increase the yields of three MPs (yellow, orange, and red pigments) by $115.70,141.52$, and $100.88 \%$, respectively, and reached $67.05,53.83$, and $86.25 \mathrm{U} / \mathrm{mL}$, respectively, at $30^{\circ} \mathrm{C}, 200 \mathrm{rpm}$ for 2 days, then at $25^{\circ} \mathrm{C}, 150 \mathrm{rpm}$ for 13 days. The amount of inoculum, carbon source, and glycerol have a great impact on the production of Monascus pigments. Due to the differences in strains, inoculum, carbon source, and culture conditions, there is a gap between the yield of Monascus pigments studied by us and that in the literature.

Monascus purpureus M1 is a stable producer of MK; Zhang et al. found that the maximal yield of MK $(68.6 \mathrm{mg} / \mathrm{L})$ was observed on day 8 in the original medium, and the maximal yield of red pigment was $40 \mathrm{U} / \mathrm{mL}$ [41]. The maximum increase in MK production was observed when treated with $25 \mu \mathrm{M} \gamma$-heptalactone. On day 15, the yield of MK reached $187.44 \mathrm{mg} / \mathrm{L}$, which was $62.38 \%$ higher than that in the control $(p<0.05)$. The difference in the optimal inoculation amount required by different fungal strains to reach the highest yield of MPs and MK can be attributed to the composition of the culture medium, growth conditions, environmental stress, and the efficacy of fungal strains. 
The apparent increase in secretion on the mycelial surface was also consistent with the genetic results. In our study, the exogenous addition of $\gamma$-heptalactone induced mycelial and spore changes, and the upregulation of three genes, lae $A, b r l A$, and wet $A$, was detected, which is consistent with the findings of a previous study that added butyrolactone to Aspergillus $[53,67]$. In recent years, population induction in filamentous fungi has also been reported, and both fungal morphology and secondary metabolite production are related to the cell population density $[7,68,69]$. Quorum sensing (QS) exists in a variety of filamentous fungi, and farnesol, tyrosol, lactones, linoleic acid, and oxylipins (oxytetracycline) are among the self-induced quorum sensing molecules (QSMs) that regulate QS behaviors, such as mycobacterial morphology and secondary metabolite alterations [52,70,71]. In A. terreus, the addition of butyrolactone I caused a significant increase in lovastatin production and an increase in mycelial tip number and spore production. It was also noted that the addition of butyrolactone I affected the number of spores on apical mycelia, induced morphological and sporulation changes in A. terreus, and enhanced secondary metabolite production $[52,53]$. Moreover, an increase in the hyphal tip numbers and sporulation has been reported for cultures supplemented with butyrolactone I $[72,73]$. $\gamma$-Heptalactone affected the production of penicillin in A. nidulans and increased the expression level of the related genes, compared with the untreated control group. This is consistent with previous reports on butyrolactone as QSMs in filamentous fungi [50]. Butyrolactone can affect the production of lovastatin, because it acts as a quorum-sensing molecule in A. terrestris. The lactones act as quorum sensing molecules and affect the yield of metabolites through quorum sensing [51-53].

In our study, the exogenous addition of $\gamma$-heptalactone induced mycelial and spore changes, and the upregulation of three genes, lae $A, \operatorname{brl} A$, and wet $A$, was detected, which is consistent with the finding in the study of adding butyrolactone I to Aspergillus [53]. The effect of $\gamma$-heptalactone on the growth and development of the bacterium is presumed to be mediated by LaeA, BrlA, and WetA $[74,75]$. Similar to that in Aspergillus, it has been reported that four proteins, VeA, VelB, VelC, and VosA, together with a global regulator, LaeA, were responsible for the regulation of the hyphal organization and the switch between primary and secondary metabolism [76-78]. Spores production is also partly regulated by the LaeA protein. BrlA, AbaA, and WetA are three key regulators that control conidiophore and bud formation, petiole emergence, and conidiophore maturation and spore viability, sequentially $[78,79]$. Our results showed that $\gamma$-heptalactone treatment significantly affected the mycelial development and spore morphology of Monascus, and upregulated the expression of $\operatorname{brl} A$, wet $A$, and lae $A$, implying a possible effect of $\gamma$-heptalactone treatment on the control of cellular differentiation in Monascus.

The regulation of secondary metabolite production is thought to be a fundamental feature of QSMs. The addition of QSMs not only affects the morphology of filamentous fungi, but also enhances the synthesis of metabolites. Our study showed that $\gamma$-heptalactone can affect the metabolic synthesis of Monascus and cause morphological changes, possibly acting in a population-sensing-like manner, and thus might be among the inducing molecules. $\gamma$-heptalactone effectively increased the yields of MPs and MK, and regulated the expression of genes related to MPs and MK biosynthesis and metabolism. The underlying mechanism of $\gamma$-heptalactone on metabolites might be related to the development of mycelia, which may be associated with QS. This study provides a new strategy to enhance the secondary metabolites of Monascus, and, therefore, the detailed mechanism of the effect on the secondary metabolites of Monascus needs to be further investigated.

\section{Conclusions}

The $\gamma$-heptalactone effectively increased the yields of MPs and MK, as well as the regulation of the gene expression related to them. The underlying mechanism of $\gamma$-heptalactone on metabolites might be related to the development of mycelial, which may be associated with QS. This study provides a new strategy to enhance the secondary metabolites of Monascus, and, therefore, the detailed mechanism of the effect on the secondary metabolites of Monascus needs to be further investigated. 


\begin{abstract}
Author Contributions: Conceptualization, R.S.; methodology, R.S. and Y.L.; software, R.S. and Q.L.; validation, R.S. and Y.L.; formal analysis, R.S. and Q.L.; investigation, R.S., Y.L. and Q.L; resources, W.C. and C.W.; data curation, R.S. and Q.L. writing—original draft preparation, R.S.; writing-review and editing, R.S. and W.C.; visualization, R.S. and Q.L.; supervision, W.C.; project administration, C.W.; funding acquisition, C.W. All authors have read and agreed to the published version of the manuscript.

Funding: This research was funded by the Beijing Municipal Natural Science Foundation-Beijing Municipal Education Commission Science and Technology Plan Key Joint Project, grant number KZ202010011016; the Beijing Engineering Technology Research Center Platform Construction Project, grant number 19008021109; and The Construction of High-precision Disciplines in Beijing, Food Science and Engineering, grant number 19008021085.
\end{abstract}

Institutional Review Board Statement: Not applicable for studies involving humans or animals.

Informed Consent Statement: Not applicable for studies involving humans.

Data Availability Statement: The data in this study are available in this article.

Acknowledgments: This research was funded by the Beijing Municipal Natural Science FoundationBeijing Municipal Education Commission Science and Technology Plan Key Joint Project (KZ202010011016), Beijing Engineering Technology Research Center Platform Construction Project (19008021109), and The Construction of High-precision Disciplines in Beijing, Food Science and Engineering (19008021085).

Conflicts of Interest: The authors declare no conflict of interest.

\title{
References
}

1. Cheng, M.; Wu, M.; Chan, H.; Chen, J.; Cheng, Y.; Chen, Y.; Chen, I.; Yuan, G. A new azaphilone metabolite from the fungus Monascus ruber. Chem. Nat. Compd. 2016, 52, 231-233. [CrossRef]

2. Feng, Y.; Shao, Y.; Chen, F. Monascus pigments. Appl. Microbiol. Biot. 2012, 96, 1421-1440. [CrossRef] [PubMed]

3. Lin, Y.; Wang, T.; Lee, M.; Su, N. Biologically active components and nutraceuticals in the Monascus-fermented rice: A review. Appl. Microbiol. Biot. 2008, 77, 965-973. [CrossRef] [PubMed]

4. Chen, W.; He, Y.; Zhou, Y.; Zhou, Y.; Shao, Y.; Chen, F. Edible filamentous fungi from the species Monascus: Early traditional fermentations, modern molecular biology, and future genomics. Appl. Microbiol. Biot. 2015, 14, 555-567.

5. Lv, J.; Qian, G.; Chen, L.; Liu, H.; Zhang, G. Efficient biosynthesis of natural yellow pigments by Monascus purpureus in a novel integrated fermentation system. J. Agr. Food Chem. 2018, 66, 918-925. [CrossRef]

6. Su, Y.; Wang, J.; Lin, T.; Pan, T. Production of the secondary metabolites $\gamma$-aminobutyric acid and monacolin K by Monascus. J. Ind. Microbiol. Biot. 2003, 30, 41-46. [CrossRef]

7. Patakova, P. Monascus secondary metabolites: Production and biological activity. J. Ind. Microbiol. Biot. 2013, 40, 169-181. [CrossRef]

8. Gao, J.; Yang, S.; Qin, J. Azaphilones: Chemistry and biology. Chem. Rev. 2013, 113, 4755-4811. [CrossRef]

9. Lin, C.; Lin, T.; Pan, T. Alleviation of metabolic syndrome by monascin and ankaflavin: The perspective of Monascus functional foods. Food Funct. 2017, 8, 2102-2109. [CrossRef]

10. Mukherjee, G.; Singh, S.K. Purification and characterization of a new red pigment from Monascus purpureus in submerged fermentation. Process Biochem. 2011, 46, 188-192. [CrossRef]

11. Vendruscolo, F.; Tosin, I.; Giachini, A.J.; Ninow, J.L. Antimicrobial activity of Monascus pigments produced in submerged fermentation. J. Food Process. Pres. 2014, 4, 1860-1865. [CrossRef]

12. Kurokawa, H.; Taninaka, A.; Shigekawa, H.; Matsui, H. The cytotoxicity of cyclophosphamide is enhanced in combination with monascus pigment. J. Clin. Biochem. Nutr. 2021, 69, 131-136. [CrossRef] [PubMed]

13. Srianta, I.; Ristiarini, S.; Nugerahani, I.; Sen, S.K.; Zhang, B.B.; Xu, G.R. Recent research and development of Monascus fermentation products. Int. Food Res. J. 2014, 21, 1-12.

14. Vendruscolo, F.; Schmidell, W.; Oliveira, D.; Ninow, J.L. Kinetic of orange pigment production from Monascus ruber on submerged fermentation. Bioproc. Biosyst. Eng. 2017, 40, 115-121. [CrossRef] [PubMed]

15. Zeng, H.; Jie, Q.; Xin, Z.; Xu, D.; Dai, C. Optimization of submerged and solid state culture conditions for Monascus pigment production and characterization of its composition and antioxidant activity. Pigm. Resin Technol. 2019, 48, 108-118. [CrossRef]

16. Patrovsky, M.; Sinovska, K.; Branska, B.; Patakova, P. Effect of initial pH, different nitrogen sources, and cultivation time on the production of yellow or orange Monascus purpureus pigments and the mycotoxin citrinin. Food Sci. Nutr. 2019, 7, 3494-3500. [CrossRef]

17. Chang, Y.; Hsu, W.; Pan, T. Monascus secondary metabolites monascin and ankaflavin inhibit activation of RBL-2H3 eells. J. Agr. Food Chem. 2015, 63, 192-199. [CrossRef]

18. Cheng, C.; Pan, T. Ankaflavin and monascin induce apoptosis in activated hepatic stellate cells through suppression of the Akt/NF- $\kappa$ B/p38 signaling pathway. J. Agr. Food Chem. 2016, 64, 9326-9334. [CrossRef] 
19. Hsu, L.; Liang, Y.; Hsu, Y.; Kuo, Y.; Pan, T. Anti-inflammatory properties of yellow and orange pigments from Monascus purpureus NTU 568. J. Agr. Food Chem. 2013, 61, 2796-2802. [CrossRef]

20. Hajjaj, H.; Blanc, P.; Groussac, E.; Uribelarrea, J.; Goma, G.; Loubiere, P. Kinetic analysis of red pigment and citrinin production by Monascus ruber as a function of organic acid accumulation. Enzyme Microb. Technol. 2000, 27, 619-625. [CrossRef]

21. Prodpran, P.; Rapeepun, M.; Chartchai, K.; Saisamorn, L. Antioxidant properties and production of monacolin K, citrinin, and red pigments during solid state fermentation of purple rice (Oryzae sativa) varieties by Monascus purpureus. Czech J. Food Sci. 2017, 35, 32-39. [CrossRef]

22. Orak, T.; Caglar, O.; Ortucu, S.; Ozkan, H.; Taskin, M. Chicken feather peptone: A new alternative nitrogen source for pigment production by Monascus purpureus. J. Biotechnol. 2018, 271, 56-62. [CrossRef] [PubMed]

23. Sweeny, J.G.; Estrada-Valdes, M.C.; Iacobucci, G.A.; Sato, H.; Sakamura, S. Photoprotection of the red pigments of Monascus anka in aqueous media by 1,4,6-trihydroxynaphthalene. J. Agr. Food Chem. 1981, 29, 1189-1193. [CrossRef]

24. Chen, M.H.; Johns, M.R. Effect of $\mathrm{pH}$ and nitrogen source on pigment production by Monascus purpureus. Appl. Microbiol. Biot. 1993, 40, 132-138. [CrossRef]

25. Endo, A. Monacolin K: A new hypocholesterolemic agent produced by a Monascus species. J. Antibiot. 1979, 32, 852-854. [CrossRef]

26. Alberts, A.W.; Chen, J.; Kuron, G.; Hunt, V.; Huff, J. Mevinolin: A highly potent competitive inhibitor of hydroxymethylglutarylcoenzyme a reductase and a cholesterol-lowering agent. Proc. Natl. Acad. Sci. USA 1980, 77, 3957-3961. [CrossRef]

27. Hong, S.Y.; Oh, J.H.; Lee, I. Simultaneous enrichment of deglycosylated ginsenosides and monacolin K in red ginseng by fermentation with Monascus pilosus. Biosci. Biotechnol. Biochem. 2011, 75, 1490-1495. [CrossRef]

28. Endo, A. The discovery and development of HMG-CoA reductase inhibitors. Atheroscler. Supp. 2004, 5, 67-80. [CrossRef]

29. Zhang, Y.R.; Chen, Z.T.; Wen, Q.Y.; Xiong, Z.X.; Cao, X.H.; Zheng, Z.H.; Zhang, Y.X.; Huang, Z.W. An overview on the biosynthesis and metabolic regulation of monacolin K/lovastatin. Food Funct. 2020, 11, 5738-5748. [CrossRef]

30. Mazza, A.; Schiavon, L.; Rigatelli, G.; Torin, G.; Montanaro, F.; Lenti, S. The short-term supplementation of monacolin K improves the lipid and metabolic patterns of hypertensive and hypercholesterolemic subjects at low cardiovascular risk. Food Funct. 2018, 9 , 3845-3852. [CrossRef]

31. Manzoni, M.; Rollini, M. Biosynthesis and biotechnological production of statins by filamentous fungi and application of these cholesterol-lowering drugs. Appl. Microbiol. Biot. 2002, 58, 555-564.

32. Sakai, K.; Kinoshita, H.; Nihira, T. Identification of mokB involved in monacolin K biosynthesis in Monascus pilosus. Biotechnol. Lett. 2009, 31, 1911-1916. [CrossRef] [PubMed]

33. Chen, Y.; Yuan, G.; Hsieh, S.; Lin, Y.; Wang, W.; Liaw, L.; Tseng, C. Identification of the mokH gene encoding transcription factor for the upregulation of monacolin K biosynthesis in Monascus pilosus. J. Agr. Food Chem. 2010, 58, 287-293. [CrossRef] [PubMed]

34. Li, L.; Chen, S.; Gao, M.; Ding, B.; Zhang, J. Acidic conditions induce the accumulation of orange Monascus pigments during liquid-state fermentation of Monascus ruber M7. Appl. Microbiol. Biot. 2019, 103, 8393-8402. [CrossRef]

35. Wang, Y.; Zhang, B.; Lu, L.; Huang, Y.; Xu, G. Enhanced production of pigments by addition of surfactants in submerged fermentation of Monascus purpureus H1102. J. Sci. Food Agr. 2013, 93, 3339-3344. [CrossRef]

36. Huang, T.; Tan, H.; Lu, F.; Chen, G.; Wu, Z. Changing oxidoreduction potential to improve water-soluble yellow pigment production with Monascus ruber CGMCC 10910. Microb. Cell Fact. 2017, 16, 208-220. [CrossRef]

37. Suraiya, S.; Kim, J.; Tak, J.Y.; Siddique, M.P.; Young, C.J.; Kim, J.K.; Kong, I. Influences of fermentation parameters on lovastatin production by Monascus purpureus using Saccharina japonica as solid fermented substrate. LWT 2018, 92, 1-9. [CrossRef]

38. Chen, G.; Yang, S.; Wang, C.; Shi, K.; Zhao, X.; Wu, Z. Investigation of the mycelial morphology of Monascus and the expression of pigment biosynthetic genes in high-salt-stress fermentation. Appl. Microbiol. Biot. 2020, 104, 2469-2479. [CrossRef]

39. Babitha, S.; Soccol, C.R.; Pandey, A. Effect of stress on growth, pigment production and morphology of Monascus sp. in solid cultures. J. Basic Microb. 2007, 47, 118-126. [CrossRef]

40. Liao, Q.; Liu, Y.; Zhang, J.; Li, L.; Gao, M. A low-frequency magnetic field regulates Monascus pigments synthesis via reactive oxygen species in M. purpureus. Process Biochem. 2019, 86, 16-24. [CrossRef]

41. Zhang, C.; Liang, J.; Yang, L.; Chai, S.Y.; Zhang, C.X.; Sun, B.G.; Wang, C.T. Glutamic acid promotes monacolin K production and monacolin $\mathrm{K}$ biosynthetic gene cluster expression in Monascus. AMB Express 2017, 7, 1-9. [CrossRef] [PubMed]

42. Yang, X.L.; Xiang, L.B.; Dong, Y.; Cao, Y.P.; Wang, C.T. Effect of nonionic surfactant Brij 35 on morphology, cloud point, and pigment stability in Monascus extractive fermentation. J. Sci. Food Agr. 2020, 100, 4521-4530. [CrossRef] [PubMed]

43. Qian, G.; Huang, J.; Farhadi, A.; Zhang, B. Ethanol addition elevates cell respiratory activity and causes overproduction of natural yellow pigments in submerged fermentation of Monascus purpureus. LWT 2021, 139, 110534. [CrossRef]

44. Huang, Z.B.; Zhang, L.J.; Wang, Y.L.; Gao, H.; Li, X.J.; Huang, X.Y.; Huang, T. Effects of rutin and its derivatives on citrinin production by Monascus aurantiacus Li AS3.4384 in liquid fermentation using different types of media. Food Chem. 2019, 284, 205-212. [CrossRef] [PubMed]

45. Chen, D.; Wang, Y.R.; Chen, M.H.; Fan, P.; Li, G.L.; Wang, C.L. Ammonium nitrate regulated the color characteristic changes of pigments in Monascus purpureus M9. AMB Express 2021, 11, 3-13. [CrossRef]

46. Huang, J.; Liao, N.Q.; Li, H.M. Linoleic acid enhance the production of monacolin K and red pigments in Monascus ruber by activating mokH and mokA, and by accelerating cAMP-PKA pathway. Int. J. Biol. Macromol. 2018, 109, 950-954. [CrossRef] 
47. Lai, Y.; Wang, L.; Qing, L.; Chen, F. Effects of cyclic AMP on development and secondary metabolites of Monascus ruber M-7. Lett. Appl. Microbiol. 2011, 52, 420-426. [CrossRef]

48. Kataoka, M.; Honda, K.; Sakamoto, K.; Shimizu, S. Microbial enzymes involved in lactone compound metabolism and their biotechnological applications. Appl. Microbiol. Biotechnol. 2007, 75, 257-266. [CrossRef]

49. Krings, U.; Berger, R.G. Biotechnological production of flavours and fragrances. Appl. Microbiol. Biotechnol. 1998, 49, 1-8. [CrossRef]

50. Williams, H.E.; Steele, J.C.P.; Clements, M.O.; Keshavarz, T. $\gamma$-Heptalactone is an endogenously produced quorum-sensing molecule regulating growth and secondary metabolite production by Aspergillus nidulans. Appl. Microbiol. Biot. 2012, 96, 773-781. [CrossRef]

51. Schimmel, T.G.; Coffman, A.D.; Parsons, S.J. Effect of butyrolactone I on the producing fungus, Aspergillus terreus. Appl. Environ. Microbiol. 1998, 64, 3707-3712. [CrossRef] [PubMed]

52. Raina, S.; Vizio, D.; Palonen, E.K.; Odell, M.; Brandt, A.M.; Soini, J.T.; Keshavarz, T. Is quorum sensing involved in lovastatin production in the filamentous fungus Aspergillus terreus? Process Biochem. 2012, 47, 843-852. [CrossRef]

53. Palonen, E.K.; Raina, S.; Brandt, A.; Meriluoto, J.; Keshavarz, T.; Soini, J.T. Transcriptomic complexity of Aspergillus terreus velvet gene family under the influence of butyrolactone I. Microorganisms 2017, 5, 12. [CrossRef]

54. Zhang, C.; Zhang, H.; Zhu, Q.Q.; Hao, S.; Chai, S.Y.; Li, Y.H.; Jiao, Z.; Shi, J.C.; Sun, B.G.; Wang, C.T. Overexpression of global regulator laeA increases secondary metabolite production in Monascus purpureus. Appl. Microbiol. Biot. 2020, 104, 1-12. [CrossRef] [PubMed]

55. Yang, X.L.; Xiang, L.B.; Dong, Y.; Zhang, C.; Cao, Y.P.; Wang, C.T. Promotion of monacolin K production in Monascus extractive fermentation: The variation in fungal morphology and in the expression levels of biosynthetic gene clusters. J. Sci. Food Agr. 2021, 101, 5652-5659. [CrossRef]

56. Chen, W.P.; Chen, R.F.; Liu, Q.P.; He, Y.; He, K.; Ding, X.L.; Kang, L.J.; Guo, X.X.; Xie, N.N.; Chen, F.S. Orange, red, yellow: Biosynthesis of azaphilone pigments in Monascus fungi. Chem. Sci. 2017, 8, 4917-4925. [CrossRef]

57. Chen, W.P.; Feng, Y.L.; Molnár, I.; Chen, F.S. Nature and nurture: Confluence of pathway determinism with metabolic and chemical serendipity diversifies Monascus azaphilone pigments. Nat. Prod. Rep. 2019, 36, 561-572. [CrossRef]

58. Embaby, A.M.; Hussein, M.N.; Hussein, A. Monascus orange and red pigments production by Monascus purpureus ATCC16436 through co-solid state fermentation of corn cob and glycerol: An eco-friendly environmental low cost approach. PLoS ONE 2018, 13, e0207755. [CrossRef]

59. Zhang, C.; Chai, S.Y.; Hao, S.; Zhang, A.A.; Zhu, Q.Q.; Zhang, H.; Wang, C.T. Effects of glutamic acid on the production of monacolin K in four high-yield monacolin K strains in Monascus. Appl. Microbiol. Biot. 2019, 103, 5301-5310. [CrossRef]

60. Zhang, C.; Liang, J.; Zhang, A.A.; Hao, S.; Zhang, H.; Zhu, Q.Q.; Sun, B.G.; Wang, C.T. Overexpression of monacolin K biosynthesis genes in the Monascus purpureus azaphilone polyketide pathway. J. Agric. Food Chem. 2019, 67, 2563-2569. [CrossRef]

61. Zhang, C.; Zhu, Q.Q.; Zhang, H.; Zhang, N.; Yang, X.L.; Shi, J.C.; Sun, B.G.; Wang, C.T. Effects on the sporulation and secondary metabolism yields of Monascus purpureus with mokH gene deletion and overexpression. Fungal Biol. 2020, 124, 661-670. [CrossRef] [PubMed]

62. Erkaya, S.; Arslan, N.P.; Orak, T.; Esim, N.; Taskin, M. Evaluation of tyrosol and farnesol as inducer in pigment production by Monascus purpureu ATCC16365. J. Basic Microb. 2020, 60, 669-678. [CrossRef] [PubMed]

63. Balakrishnan, B.; Chen, C.; Pan, T.; Kwon, H. Mpp7 controls regioselective Knoevenagel condensation during the biosynthesis of Monascus azaphilone pigments. Tetrahedron Lett. 2014, 55, 1640-1643. [CrossRef]

64. Liang, B.; Du, X.J.; Li, P.; Sun, C.C.; Wang, S. Investigation of citrinin and pigment biosynthesis mechanisms in Monascus purpureus by transcriptomic analysis. Front. Microbiol. 2018, 9, 1374. [CrossRef]

65. Chai, X.Y.; Ai, Z.L.; Liu, J.; Guo, T.; Wu, J.Y.; Bai, J.; Lin, Q.L. Effects of pigment and citrinin biosynthesis on the metabolism and morphology of Monascus purpureus in submerged fermentation. Food Sci. Biotechnol. 2020, 29, 927-937. [CrossRef]

66. Chen, Y.P.; Tseng, C.P.; Liaw, L.L.; Wang, C.L.; Chen, I.C.; Wu, W.J.; Wu, M.D.; Yuan, G.F. Cloning and characterization of monacolin K biosynthetic gene cluster from Monascus pilosus. J. Agr. Food Chem. 2008, 56, 5639-5646. [CrossRef]

67. Palonen, E.K.; Neffling, M.R.; Raina, S.; Brandt, A.; Keshavarz, T.; Meriluoto, J.; Soini, J. Butyrolactone I quantification from lovastatin producing Aspergillus terreususing tandem mass spectrometry-evidence of signaling functions. Microorganisms 2014, 2 , 111-127. [CrossRef]

68. Safari, M.; Amache, R.; Esmaeilishirazifard, E.; Keshavarz, T. Microbial metabolism of quorum-sensing molecules acyl-homoserine lactones, $\gamma$-heptalactone and other lactones. Appl. Microbiol. Biot. 2014, 98, 3401-3412. [CrossRef]

69. Piewngam, P.; Zheng, Y.; Nguyen, T.H.; Dickey, S.W.; Joo, H.S.; Villaruz, A.E.; Glose, K.A.; Fisher, E.L.; Hunt, R.L.; Li, B.; et al. Pathogen elimination by probiotic Bacillus via signaling interference. Nature 2018, 562, 532-537. [CrossRef]

70. Raina, S.; Odell, M.; Keshavarz, T. Quorum sensing as a method for improving sclerotiorin production in Penicillium sclerotiorum. J. Biotechnol. 2010, 148, 91-98. [CrossRef]

71. Recio, E.; Colinas, A.; Rumbero, A.; Aparicio, F.; Martin, J.F. PI factor, a novel type quorum-sensing inducer elicits pimaricin production in streptomyces natalensis. J. Biol. Chem. 2004, 279, 41586-41593. [CrossRef] [PubMed]

72. Sorrentino, F.; Roy, I.; Keshavarz, T. Impact of linoleic acid supplementation on lovastatin production in Aspergillus terreus cultures. Appl. Microbiol. Biot. 2010, 88, 65-73. [CrossRef] [PubMed] 
73. Takano, E.; Chakraburtty, R.; Nihira, T.; Yamada, Y.; Bibb, M. A complex role for the $\gamma$-butyrolactone SCB1 in regulating antibiotic production in Streptomyces coelicolor A3(2). Mol. Microbiol. 2001, 41, 1015-1028. [CrossRef] [PubMed]

74. Bok, J.W.; Balajee, S.A.; Marr, K.A.; Andes, D.; Nielsen, K.; Frisvad, J.C.; Keller, N.P. LaeA, a regulator of morphogenetic fungal virulence factors. Eukary. Cell 2005, 4, 1574-1582. [CrossRef] [PubMed]

75. Sarikaya, B.O.; Bayram, O.; Valerius, O.; Park, H.; Irniger, S.; Gerke, J.; Ni, M.N.; Han, K.H.; Yu, J.H.; Braus, G.H. LaeA control of velvet family regulatory proteins for light-dependent and fungal cell-type specificity. PLoS Genet. 2010, 6, e1001226. [CrossRef]

76. Kale, S.P.; Milde, L.; Trapp, M.K.; Frisvad, J.C.; Keller, N.P.; Bok, J.W. Requirement of laeA for secondary metabolism and sclerotial production in Aspergillus flavus. Fungal Genet. Biol. 2008, 45, 1422-1429. [CrossRef]

77. Chang, P.K.; Scharfenstein, L.L.; Ehrlich, K.C.; Wei, Q.; Bhatnagar, D.; Ingber, B.F. Effects of laeA deletion on Aspergillus flavus conidial development and hydrophobicity may contribute to loss of aflatoxin production. Fungal Biol. 2012, 116, $298-307$. [CrossRef]

78. Jia, L.L.; Yu, J.H.; Chen, F.S.; Chen, W.P. Characterization of the asexual developmental genes brlA and wetA in Monascus ruber M7. Fungal Genet. Biol. 2021, 151, 103564. [CrossRef]

79. Yang, H.; Wang, X.; Li, Z.J.; Guo, Q.B.; Yang, M.G.; Chen, D.; Wang, C.L. The effect of blue light on the production of citrinin in Monascus purpureus 99 by regulating the mraox gene through lncRNA AOANCR. Toxins 2019, 11, 536. [CrossRef] 